\title{
HAK PEMELIHARAAN ANAK BAGI MUALAF: KONFLIK UNDANG-UNDANG DI MALAYSIA
}

\section{(Custody of Mualaf's Child: Resolution of Law Conflict in Malaysia)}

Redwan Yasin*

Redwan.hjyasin@gmail.com

Fakulti Undang-undang, Universiti Kebangsaan Malaysia.

Noor Aziah Mohd Awal

naha61@gmail.com

Suruhanjaya Hak Asasi Manusia (SUHAKAM).

Fakulti Undang-undang, Universiti Kebangsaan Malaysia.

Nurhafilah Musa

hafilah@ukm.edu.my

Fakulti Undang-undang, Universiti Kebangsaan Malaysia.

Terbit dalam talian (published online): 7 Januari 2021

Sila rujuk: Redwan Yasin, Noor Aziah Mohd Awal dan Nurhafilah Musa (2021). Hak Pemeliharaan Anak bagi Mualaf: Konflik Undang-undang di Malaysia. Kanun: Jurnal Undang-undang Malaysia, 33(1), 51-78.

\begin{abstract}
Abstrak
Pertikaian hak pemeliharaan anak dalam kalangan mualaf yang memeluk agama Islam dan mempunyai rekod pendaftaran perkahwinan di bawah akta sivil di Malaysia sering menjadi perbincangan. Semenjak awal akta ini dikuatkuasakan, permasalahan yang timbul adalah berkaitan dengan ketergantungan hak oleh pasangan mualaf yang memeluk Islam kerana tidak mempunyai hak untuk memfailkan tuntutan perceraian di bawah Akta Memperbaharui Undang-undang (Perkahwinan dan Perceraian) 1976 (Akta 164) terutamanya yang melibatkan seksyen 3 dan seksyen


51 akta tersebut. Namun demikian, pada tahun 2017 pindaan undangundang telah dilakukan terhadap kedua-dua peruntukan tersebut bagi menyelesaikan kemelut perundangan yang timbul dan mewujudkan undang-undang yang lebih efisien. Oleh yang demikian, penulisan artikel ini bertujuan untuk membandingkan konsep hadanah undangundang Islam dan hak pemeliharaan anak menurut undang-undang sivil di Malaysia. Analisis dilakukan terhadap faktor berlakunya konflik yang sering kali terjadi dan menjelaskan implikasi pindaan 2017 (Akta 164) terhadap prosedur permohonan hak pemeliharaan anak pasangan mualaf. Kaedah kajian kepustakaan digunakan bagi mengumpulkan data untuk dianalisis mengikut kaedah analisis kandungan. Hasil penulisan menunjukkan bahawa pindaan undang-undang yang dilakukan berpotensi untuk menyelesaikan isu perceraian mualaf yang sebelum ini terikat dengan perkahwinan sivil tanpa sebarang hak untuk memohon petisyen. Pindaan ini juga mampu memberikan ruang keadilan kepada kedua-dua belah pihak untuk memohon hak pemeliharaan anak setelah urusan perceraian berjaya diselesaikan di bawah mahkamah sivil. dalam hal ini prinsip kebajikan anak tetap perlu menjadi keutamaan dalam setiap keadaan, bukan sekadar perdebatan tentang hak ibu atau bapa yang berstatus mualaf semata-mata.

Kata kunci: Hak pemeliharaan anak, mualaf, undang-undang islam, undang-undang sivil

\section{Abstract}

In Malaysia, disputes concerning custody rights are among the frequently-debated topics in cases of conversion to Islam, if it involves a marriage previously registered under civil law. Since coming into force, a frequent issue that has arisen is the rights of convert spouses under the Law Reform (Marriage and Divorce) Act 1976 (Act 164), specifically sections 3 and 51, as the muallaf (convert to Islam) does not have the right to petition for dissolution of marriage under this Act. However, in 2017, amendments were made to this Act to bring about better and more efficient resolutions to any legal issues arising in such matters. Therefore, this article aims to compare the concept of hadhanah (care and protection of children) in Islamic law with custody rights under Malaysian civil law. The factors that frequently give rise to conflict were analysed, as well as the implications of the 2017 amendments (Act 164) concerning the application procedure for custody rights of convert spouses. Library research was employed to collect data for content analysis. The findings show that the amendments are able to aid in 
resolving issues concerning divorces of converts who were previously bound to a civil marriage without the right to petition for dissolution. The amendment also allows both spouses the right to apply for custody of a child after their divorce has been finalized by the civil court. The study further recommends that in such cases, child welfare, and not the rights of the converted parent, should be the main concern at all times.

Keywords: Child custody, Muallaf, Islamic law, civil law

\section{PENDAHULUAN}

Perceraian merupakan jalan penyelesaian terakhir yang diberikan oleh syariat Islam apabila sesebuah ikatan perkahwinan yang terjalin tidak mampu lagi diteruskan. Perkahwian yang tidak bahagia boleh membawa implikasi yang buruk kepada pasangan dan anak-anak. Apabila berlakunya perceraian antara pasangan, salah seorang pasangan akan membuat pelbagai tuntutan antaranya termasuklah hak pemeliharaan anak, nafkah dan harta sepencarian. Seperti yang telah diketahui umum bahawa Malaysia sebuah negara yang mengamalkan dua bentuk sistem perundangan, iaitu sistem perundangan syariah dan sivil. Undang-undang Islam hanya terpakai kepada orang Islam dan diletakkan di bawah bidang kuasa negeri.

Perincian terhadap peruntukan di bawah undang-undang Islam seperti yang terkandung dalam Jadual 9, Senarai 2(1) adalah berkaitan dengan hukum syarak dan undang-undang diri dan keluarga bagi penganut agama Islam, termasuklah hukum syarak berhubung dengan hal mewarisi harta berwasiat, pertunangan, perkahwinan, perceraian, mas kahwin, nafkah, pengambilan anak angkat, penjagaan anak dan sebagainya. Kesemua perkara tersebut dibicarakan di bawah mahkamah syariah yang hanya melibatkan orang Islam kerana tidak mempunyai bidang kuasa mutlak terhadap golongan bukan Islam (Mohamed Azam, 2006: 60). Jika diperhatikan sebelum tahun 1988, wujud campur tangan mahkamah sivil terhadap hal ehwal orang Islam, tetapi apabila Pindaan 12 (1A) Perlembagaan Persekutuan diwujudkan, maka diputuskan bahawa mahkamah sivil tidak mempunyai bidang kuasa terhadap perkaraperkara yang telah diperuntukkan secara secara sah oleh Perlembagaan Persekutuan kepada mahkamah syariah, khususnya bagi kes yang melibatkan individu beragama Islam (Ramizah, 2009: 16).

Sebelum berlakunyapindaan2017AktaPerkahwinan danPerceraian (Akta 164), konflik pertindihan bidang kuasa antara mahkamah sivil dengan syariah masih kerap berlaku terutamanya apabila melibatkan pertikaian orang Islam dan 
bukan Islam. Antaranya termasuklah isu pasangan yang pernah berkahwin di bawah Akta Memperbaharui Undang-Undang (Perkahwinan dan Perceraian) 1976 (Akta 164), dan kemudiannya salah seorang daripada pasangan tersebut memeluk Islam dan memegang status mualaf. Bagi penyelesaian kes sebegini, perkara utama yang perlu diselesaikan sebelum perbincangan mengenai hak pemeliharaan anak ialah pembubaran perkahwinan lama yang perlu dilakukan di bawah mahkamah sivil memandangkan perkahwinan tersebut didaftarkan di bawah Akta 164. Malah sebarang tuntutan relief yang ingin dilakukan oleh kedua-dua belah pihak perlulah merujuk prosedur undang-undang sivil walaupun melibatkan individu yang telah memeluk agama Islam.

Namun begitu, bermula pada tahun 2017, usaha terbaik telah dilakukan bagi mewujudkan penyelesaian yang efisien tanpa menzalimi mana-mana pihak yang bertikai, iaitu pindaan dua seksyen utama yang melibatkan hak perbicaraan dan pemakaian akta termasuklah orang Islam dalam kes-kes tertentu dan juga hak permohonan petisyen perceraian oleh pihak yang memeluk Islam di bawah akta sivil. Natijahnya, kedua-dua pihak berupaya mendapatkan keadilan dari sudut undang-undang melalui perbicaraan pada platform yang sepatutnya, iaitu di mahkamah sivil dengan merujuk akta sivil bagi tatacara perceraian. Cara ini sekali gus dapat memberikan implikasi positif terhadap kelancaran permohonan hak pemeliharaan anak oleh keduadua pihak apabila isu perceraian tersebut berjaya diselesaikan.

\section{HADANAH MENURUT UNDANG-UNDANG ISLAM DI MALAYSIA}

Dalam konteks undang-undang Islam, pemeliharaan anak disebut sebagai hadanah yang bermaksud pemeliharaan dari sudut fizikal dan perbuatan mengasuh anak yang dilakukan oleh seorang hadin (lelaki) atau hadinah (perempuan) terhadap diri anak atau seseorang yang tidak mampu menguruskan dirinya sendiri. Tafsiran bagi maksud konsep mengasuh adalah berbuat sesuatu yang mendatangkan manfaat dan melindunginya daripada segala kemudaratan dengan sepenuh perasaan (al-Sharbini, 1978: 452). Secara amnya, para ulama meletakkan dua elemen utama yang berkait rapat dengan hadanah, iaitu pemeliharaan fizikal, mental dan emosi yang menyeluruh dan memberikan pendidikan yang sempurna termasuklah terhadap golongan yang tidak berkemampuan untuk menguruskan atau melakukannya sendiri, sama ada atas sebab tidak mumaiyiz seperti anak dalam jagaan atau golongan safih yang kurang akal. Oleh yang demikian, perlu difahami bahawa tempoh tamat keutamaan bagi autoriti hadanah adalah apabila anak mencapai tahap mumaiyiz dan selepas itu dikira 
sebagai hak penjagaan bagi anak yang telah baligh (al-Jaziri, 1969:569). Para ulama membezakan kedua-dua tersebut kerana keperluan diri anak bagi kedua-dua tempoh tersebut adalah berbeza. Pada peringkat hadanah mereka lebih memerlukan susuan ibu dan kasih sayang, manakala pada peringkat seterusnya lebih memerlukan kebajikan dari sudut fizikal dan emosi yang melibatkan tumbesaran diri.

Antara tanggungjawab yang perlu dilaksanakan terhadap mereka termasuklah menyediakan dan menguruskan segala keperluan hidup seperti makanan, minuman, pakaian, tempat tinggal dan kelengkapan diri yang bersesuaian untuk mereka (al-Zuhaily, 1997). Kadangkala terdapat segelintir pihak yang hanya memahami bahawa hadanah sekadar hak keistimewaan yang diberikan oleh Islam atau undang-undang syariah kepada mereka sebagai ibu bapa atau penjaga. Namun demikian, hadanah seharusnya dihayati dan dilaksanakan dengan penuh tanggungjawab agar tidak menzalimi hak anak dalam lingkungan umur anak yang sepatutnya diutamakan. Tanggungjawab melindungi mereka merangkumi setiap aspek kehidupan diri. Tanggungjawab ini tidak seharusnya diabaikan dan perlu dititikberatkan seperti hak-hak lain yang dipertanggungjawabkan atas wali atau hadin seperti nafkah anak yang masih di bawah tanggungan (Normi, 2004: 36). Bagi tujuan itu, maka agama Islam lebih meraikan golongan ibu dari sudut keutamaan dalam penetapan hak hadanah bagi anak yang masih kecil atau masih pada peringkat umur di bawah mumaiyiz. Pengiktirafan ini berpandukan sifat semula jadi yang wujud dalam diri seorang ibu sebagai insan yang dikurniakan oleh Allah SWT dengan fitrah murni dan rasa kasih sayang yang tinggi dalam jiwa, terutamanya bagi anak yang masih menyusu serta menyebabkan berlaku kesukaran untuk berpisah dari sudut fizikal mahupun emosi dengan ibunya. Persepakatan ulama muktabar Islam dalam hal ini berdasarkan dalil hadis Rasulullah SAW yang bermaksud:

Diriwayatkan bahawa seorang wanita yang telah diceraikan oleh suaminya, kemudian datang berjumpa dengan Rasulullah SAW dan menjelaskan bahawa: "Ya Rasulullah, rahimku adalah tempat mengandungkan anakku, dan dia mendapatkan susunya daripadaku, dan pangkuanku inilah yang melindunginya. Akan tetapi malangnya sekarang ayahnya (bekas suamiku) ingin mengambil hak tersebut daripadaku." Maka jawab Rasulullah SAW: "Ternyata engkaulah yang lebih berhak untuk itu selagi mana engkau masih belum berkahwin". 
Teori penetapan hak hadanah tidak seharusnya dipandang remeh kerana melibatkan hak pelbagai pihak yang perlu dititikberatkan. Penilaian terhadap kelayakan bagi seseorang yang bergelar hadin atau hadinah haruslah dilihat secara komprehensif agar tidak menzalimi mana-mana pihak. Hakikatnya, hadanah merupakan hak bagi seorang anak yang masih kecil dan memerlukan penjagaan yang teliti. Malah konsep penjagaan maslahat anak juga diakui oleh pihak undang-undang hak asasi bagi kanakkanak yang mengutamakan prinsip dasar yang sama, iaitu mengutamakan kebajikan anak kerana melibatkan kepentingan masa hadapan pembesaran anak dari sudut emosi, mental dan fizikal (Dina, 2012: 146). Hal ini bukan sekadar perbincangan soal hak siapa semata-mata, bahkan pihak mendapat hak pemeliharaan memikul amanah yang besar untuk memastikan kebaikan dan kebajikan anak sentiasa terpelihara. Segala keperluan dan kebaikan bagi diri anak hendaklah mengatasi segalanya dan diletakkan sebagai puncak keutamaan sebelum mengambil kira pertimbangan yang lain, (Mohamed Azam, 2014: 6). Sekiranya berlaku kesilapan terhadap penetapan hak hadanah atas sebab pengabaian terhadap tanggungjawab tersebut, maka penganiayaan sebenar akan dirasai oleh anak. Oleh yang demikian, ibu bapa perlu mengambil perhatian dan perlu memastikan kepentingan anak tidak terabai sekalipun perceraian telah berlaku antara mereka (Raihanah, 2007: 92).

Dari sudut pelaksanaan undang-undang di Malaysia, segala inti pati hukum syarak berkaitan dengan konsep hadanah telah diperuntukkan dalam Undang-Undang Keluarga Islam yang diguna pakai oleh negerinegeri di seluruh Malaysia untuk membicarakan kes kekeluargaan yang melibatkan individu beragama Islam. Sebagai contoh, pada Bahagian VII Akta Undang-Undang Keluarga Islam (Wilayah-wilayah Persekutuan) 1984 (Akta 303) menjelaskan secara keseluruhannya di bawah bab Hadanah dan Penjagaan Anak menurut kaedah perundangan syariah. Peruntukan undang-undang tersebut meliputi golongan yang berhak untuk mendapatkan hak hadanah seperti yang terkandung dalam seksyen 81(1) yang mengutamakan ibu dan juga keseluruhan turutan individu lain dalam seksyen 81(2) Akta 303. Kelayakan bagi membolehkan seseorang mendapatkan hak pemeliharaan menurut undang-undang Islam terkandung dalam seksyen 82 Akta 303, iaitu;

Seseorang yang mempunyai hak mendidik seseorang kanak-kanak, adalah berhak menjalankan hak terhadap hadhanah jika- 
(a) dia adalah seorang Islam;

(b) dia adalah sempurna akal;

(c) dia berumur yang melayakkan dia memberikan kepada kanak-kanak itu jagaan dan kasih sayang yang mungkin diperlukan oleh kanak-kanak itu;

(d) dia berkelakuan baik dari segi akhlak Islamiah; dan

(e) dia tinggal di tempat di mana kanak-kanak itu tidak mungkin menghadapi apa-apa akibat buruk dari segi akhlak atau jasmani.

Peruntukan undang-undang syariah berkaitan dengan hak hadanah di Malaysia dilihat selari dengan ketetapan hukum syarak yang asli kerana mengutamakan ibu bagi anak yang masih kecil selagi ibu tersebut tidak menjalinkan ikatan perkahwinan yang baharu secara sah. Peruntukan dalam seksyen tersebut juga menjelaskan tentang turutan individu yang berhak untuk hadanah seperti nenek sebelah ibu dan bapa. Kelayakan tersebut bukanlah bersifat mutlak, akan tetapi tertakluk pada bidang kuasa mahkamah untuk mendengar dan menentukan hak hadanah kepada manamana pihak yang dirasakan oleh mahkamah patut dan mampu memelihara hak paling utama, iaitu kebaikan dan kebajikan diri anak seperti yang terkandung dalam seksyen 86(1)(2) Akta 303:

(1) Walau apa pun peruntukan seksyen 81, Mahkamah boleh pada bilabila masa dengan perintah memilih untuk meletakkan seseorang kanakkanak dalam jagaan salah seorang daripada orang yang tersebut di dalam seksyen itu atau, jika ada hal keadaan yang luar biasa yang menyebabkan tidak diingini bagi kanak-kanak itu diamanahkan kepada salah seorang daripada orang-orang itu, Mahkamah boleh dengan perintah meletakkan kanak-kanak itu dalam jagaan mana-mana orang lain atau mana-mana persatuan yang tujuannya adalah termasuk kebajikan kanak-kanak.

(2) Untuk memutuskan dalam jagaan siapakah seseorang kanak-kanak patut diletakkan, pertimbangan yang utama ialah kebajikan kanakkanak itu dan, tertakluk kepada pertimbangan itu, Mahkamah hendaklah memberi perhatian kepada-

(a) kemahuan ibu bapa kanak-kanak itu; dan 
(b) kemahuan kanak-kanak itu, jika dia telah meningkat umur dapat menyatakan sesuatu pendapatnya sendiri.

Selain itu, beberapa aspek yang diklasifikasikan sebagai syarat bagi melayakkan diri untuk mendapatkan hak penjagaan anak adalah seperti beragama Islam, sempurna akal, kelayakan umur, berkelakuan dari sudut akhlak Islamiyah dan menyediakan tempat tinggal yang memberikan keselesaan kepada anak untuk membesar dengan sempurna. Peruntukan seksyen 82(a) Akta 303 amat signifikan dengan penulisan artikel ini kerana dengan jelas menyatakan bahawa syarat kelayakan pertama bagi penjaga anak menurut undang-undang syariah di Malaysia ialah beragama Islam. Maka selari dengan kehendak peruntukan seksyen 83(d) Akta 303, dapatlah difahami bahawa seorang yang bukan beragama Islam atau keluar daripada agama Islam seperti murtad tidak layak menjadi penjaga utama untuk membesarkan anak-anak.

Falsafah penetapan syarat tersebut berpandukan landasan hukum yang dipegang oleh pendapat mazhab Shafii dan mazhab Hambali yang menjelaskan bahawa hadanah merupakan salah satu bentuk hak penguasaan diri yang tidak seharusnya dipegang oleh golongan bukan Islam terhadap golongan Muslim. Pendapat tersebut berpandukan dalil firman Allah SWT dalam Surah al-Nisa, ayat 141 berkaitan dengan larangan meletakkan golongan Islam bawah kekuasaan golongan bukan Islam (Uqlah, 1984: 360). Menurut Ibnu Qudamah yang juga menjelaskan bahawa agama merupakan kriteria penting untuk dipertimbangkan sebagai salah satu kebajikan dalam menentukan hak pemeliharaan anak. Malah beliau juga menegaskan bahawa kepentingan agama dalam isu tersebut bertujuan untuk memelihara akidah yang dianuti oleh anak dan mengelakkan berlaku kerosakan atau kecelaruan dalam pelaksanaan komitmen beragama bagi anak tersebut (Ibn Qudamah, t.t.: 612)

Namun begitu, tidak dinafikan bahawa pendapat ulama mazhab Hanafi dan Maliki menyatakan bahawa menganut agama Islam bukanlah syarat utama untuk melayakkan seseorang untuk mendapatkan hak pemeliharaan anak. Sungguhpun ibu atau bapa bukan Islam berbeza agama, namun mereka tetap dikira berhak dengan syarat mereka tidak boleh cuba untuk mempengaruhi atau merosakkan akidah anak-anak dalam hal yang berkaitan dengan kepercayaan agama, amalan keagamaan yang bertentangan dengan hukum Islam. Antara sekatan yang diberikan oleh ulama termasuklah larangan membawa kanak-kanak ke gereja dengan niat untuk mempengaruhi akidah, mengajar mereka agama selain Islam 
dengan niat untuk memesongkan fahaman agama, dan meminta mereka untuk mengambil makanan atau minuman yang diharamkan dalam Islam seperti khinzir dan arak (Mohamed Azam \& Rafeah, 2017: 39)

Selain itu, pemahaman terhadap konsep hak pemeliharaan (custody/ hadanah) haruslah dibezakan dengan hak perwalian (guardianship/ penjagaan) menurut Islam penjaga hakiki (wali) hanya merujuk bapa yang mempunyai peranan yang lebih daripada sekadar memelihara anak. Menurut hukum syarak, wali berhak untuk mengawal, mentadbir mengawasi harta dan berupaya membuat keputusan bagi pihak golongan yang tidak ahliyyah (berkelayakan untuk mentadbir diri) seperti anak yang belum mencapai umur baligh atau matang, bahkan dibolehkan untuk melakukan keputusan untuk mereka tanpa memerlukan persetujuan mereka terlebih dahulu (al-Zuhailiy, 1997). Maka dapatlah disimpulkan bahawa skop hadanah berkaitan dengan pemeliharaan fizikal anak, manakala penjagaan (wali) meliputi perkara yang lebih luas dan memberikan kesan kepada anak pada masa hadapan seperti perkahwinan memerlukan izin wali mujbir bagi anak perempuan. Menurut aplikasi undang-undang Islam, hadanah hanya akan berlaku jika anak tinggal bersama-sama dengan ibu atau bapa yang diberikan hak pemeliharaan, sedangkan untuk menjalankan tanggungjawab sebagai seorang wali (penjaga), tidak semestinya dia tinggal bersama-sama dengan anak. Oleh sebab itu, konsep perwalian diserahkan kepada pihak bapa, dan sekiranya berlaku perebutan hadanah, maka akan lebih berorientasikan kepada golongan ibu (Normi, 2007: 190).

\section{HAK PEMELIHARAAN ANAK MENURUT UNDANG-UNDANG SIVIL DI MALAYSIA}

Menurut undang-undang sivil pula, hak pemeliharaan anak diperuntukkan di bawah Akta Memperbaharui Undang-undang (Perkahwinan dan Perceraian) 1976 (164) dan juga Akta Penjagaan Anak 1961 (Akta 351). Jika diteliti, kedua-dua akta ini tidak mentakrifkan istilah hak pemeliharaan atau "custody" dengan takrifan yang spesifik. Namun begitu, pemahaman terhadap maksud hak pemeliharaan anak dapat dilihat pada peruntukan seksyen 88(1) AMU 164 yang meletakkan autoriti pihak mahkamah untuk menilai dan menentukan sama ada ibu bapa atau mana-mana pihak yang dirasakan patut dan berkelayakan untuk diberikan hak pemeliharaan untuk kepentingan anak tersebut. Elemen utama yang perlu diperhalusi 
oleh mahkamah yang mengadili kebajikan anak tersebut seperti yang termaktub dalam seksyen 88(2) Akta 164 dan seksyen 11 Akta 351, iaitu:

Seksyen 88 (2) Akta 164:

Dalam memutuskan dalam penjagaan siapa seseorang anak patut diberi perhatian utama ialah kebajikan anak itu dan tertakluk kepada ini, mahkamah hendaklah memberi perhatian kepada

(a) kemahuan ibu bapa anak itu; dan

(b) kemahuan anak itu, jika dia telah mencapai umur yang boleh menyatakan suatu pendapat bebas.

Seksyen 11 Akta 351:

The Court or a Judge, in exercising the powers conferred by this Act, shall have regard primarily to the welfare of the infant and shall, where the infant has a parent or parents, consider the wishes of such parent or both of them, as the case may be.

Menurut Shamsuddin (2011), sungguhpun kedua-dua seksyen tersebut diperuntukkan di bawah dua akta yang berbeza, namun kandungannya merujuk kehendak yang sama kerana memberikan penekanan kepada kebajikan anak. Kedua-dua seksyen tersebut juga memberikan pemahaman bahawa kebajikan anak merupakan keutamaan yang perlu didahulukan apabila timbul persoalan berkenaan pihak yang paling berhak untuk memelihara anak tersebut apabila berlaku masalah dalam intitusi perkahwinan seperti kematian dan perceraian yang melibatkan golongan bukan Muslim(Shamsuddin,2011:251). Dalam kes Mahabir Prasad [1982] 1 MLJ 189, pihak mahkamah persekutuan telah menjelaskan maksud "first and paramount consideration" bukanlah sekadar meletakkan kebajikan kanak-kanak sebagai suatu perkara yang perlu dipertimbangkan, bahkan mestilah didahulukan dan diutamakan melebihi aspek atau pertimbangan lain. Dalam kes tersebut, atas alasan mengutamakan kebajikan anak, maka pihak mahkamah telah mengambil kira keakraban anak dengan ibu dan adik-beradik, keselesaan tempat tinggal dan persekitaran anak untuk membesar dan kemahuan anak sendiri. Rayuan hak pemeliharaan oleh pihak bapa telah ditolak oleh pihak Mahkamah Persekutuan sekali gus mengekalkan keputusan mahkamah tinggi untuk memberikannya 
kepada ibu kerana berpendapat tiada kebaikan untuk mengekalkan atau mempertahankan status quo tersebut, iaitu anak-anak tinggal dengan bapa memandangkan kebajikan anak lebih terjamin dan terjaga bersama-sama dengan pihak ibu (Mimi Kamariah, 1998: 145).

Namun demikian, tidak dinafikan bahawa menurut Schepard (2004: 163), terdapat segelintir pihak yang masih kurang berpuas hati tentang penetapan kebajikan anak dalam konteks hak pemeliharaan anak kerana dilihat masih kabur dan terlalu bergantung pada budi bicara hakim yang mengadili sesuatu kes. Sehingga kini masih belum wujud sebarang peruntukan undang-undang yang spesifik atau khusus yang menunjukkan hierarki keutamaan bagi elemen yang terangkum di bawah kebajikan anak. Namun begitu, menurut beliau, antara elemen asas yang perlu dirujuk oleh pihak mahkamah dalam instrumen bagi ujian kebajikan anak termasuklah:

1. keinginan dan alasan yang diberikan oleh ibu bapa untuk mendapatkan hak penjagaan;

2. kemahuan dan pendapat anak yang dikira rasional sekiranya telah diyakini berkelayakan untuk memberikan pandangan oleh pihak mahkamah, pihak yang kebiasaannya sentiasa ada untuk menjaga anak;

3. keakraban anak dengan pihak yang menuntut dari sudut komunikasi dan hubungan dalaman seperti perasaan kasih, sayang dan kerinduan, tahap hubungan anak dengan adik beradik yang lain;

4. kemudahan dan keselesaan anak untuk tujuan persekolahan dan kediaman, kesesuaian persekitaran anak untuk membesar dalam keadaan yang sihat; dan

5. jaminan kesihatan fizikal, mental dan emosi anak supaya tidak menjadi mangsa penderaan pihak yang tidak bertanggungjawab.

Selari dengan elemen di atas, peruntukan Seksyen 89(1) Akta 164 juga menjelaskan tentang syarat keperluan bagi pihak yang ingin diberikan hak pemeliharaan anak mestilah mempuyai keupayaan dan kelayakan untuk menentukan kebaikan dan kebajikan anak terutamanya semasa dalam tempoh membesarkan anak tersebut. Berpandukan peruntukan tersebut, dapatlah juga difahami juga bahawa hak pemeliharaan tidak hanya terbatas kepada menjaga dan menguasai fizikal anak, bahkan secara keseluruhannya, merangkumi pengasuhan, pendidikan dan curahan kasih sayang kepada anak (Norliah et al., 2011: 308). Dalam kes Chang Ah May@ Chong Chow Peng (f) v Francis Teh Thian Sar [1991] 2 CLJ, 
pihak mahkamah telah membuat suatu perintah yang membenarkan hak pemeliharaan, penjagaan dan pengawalan anak yang masih bayi kepada ibu. Menurut Normi (2001: 170), pihak hakim menggunakan frasa "custody, care and control" untuk menzahirkan dengan jelas bahawa hak pemeliharaan anak bermaksud lebih daripada sekadar penjagaan bersifat luaran dari segi fizikal, malah melibatkan elemen dalaman, iaitu perasaan dan kestabilam emosi anak sepanjang tempoh pembesaran.

Selain ibu bapa kandung, Seksyen 88 Akta 164 juga meletakkan bidang kuasa kepada mahkamah untuk melantik mana-mana pihak lain yang dirasakan perlu dan wajar sebagai "legal custodian" bagi menjalankan tanggungjawab pemeliharaan anak sebagai ibu bapa angkat atau penjaga yang sah seperti yang diputuskan dalam kes Tang Kong Meng lwn Zainon bte Md Zain \& Anor. [1995] 3 MLJ 408. Dalam kes tersebut, pihak yang mendapat hak pemeliharaan anak ialah ibu bapa angkat kanak-kanak tersebut. Memandangkan tidak wujud takrifan yang khusus bagi perkataan custody atau pemeliharaan, maka mahkamah membuat kesimpulan bahawa hak tersebut bermaksud secara fizikal. Maka pihak defendan, iaitu ibu bapa angkat mendapat hak pemeliharaan dan diberikan tanggungjawab untuk mengasuh dan membesarkan anak dengan mengutamakan kebajikan dan kebaikan diri anak tersebut seperti yang diperintahkan oleh pihak mahkamah. Walau bagaimanapun, mereka dilarang untuk mengubah agama asal anak dan mencampurkan anak dalam ajaran agama Islam.

Bukan itu sahaja, malah pihak mahkamah dalam rekod penghakiman pernah memutuskan hak pemelihraan untuk diberikan anak kepada datuk dan nenek bagi memelihara kebajikan anak dengan merujuk Seksyen 11, Akta Penjagaan Anak (Akta 351) yang menyatakan tentang "primarily to the welfare of the child" seperti yang diputuskan dalam kes Chua Thye Peng lwn Kuan Huah Ong [1978] 2 MLJ 217, bahawa mahkamah perlu membuat pertimbangan tentang hak pemeliharaan anak lelaki yang berusia tujuh tahun, apabila ibu bapanya meninggal dunia, iaitu dengan memberikan penekanan tentang kebajikan anak yang tidak hanya terhad kepada perkara kebendaan dan material semata-mata. Pihak mahkamah memutuskan bahawa hak pemeliharaan anak tersebut diberikan kepada datuk dan nenek sebelah bapa dengan mengambil kira soal kebajikan anak dari sudut pendidikan moral dan keagamaan yang akan lebih terpelihara jika ibu bapanya masih hidup, dan pastinya anak tersebut akan dibesarkan dan diberikan pendidikan agama Buddha yang secukupnya (Noor Aziah, 2007: 166). Dalam kes S Thaiyalnayagam lwn Gm Kodaguda [1983] 1 MLJ 242, pihak mahkamah hanya memberikan hak akses kepada 
pemohon dan menolak permohonan hak pemeliharaan (custodial right) oleh nenek sebelah bapa. Keputusan dicapai berdasarkan pemerhatian terhadap keadaan responden yang lebih teratur dan mampu menyediakan keselesaan kepada anak berbanding dengan pemohon yang tidak terlalu mencerminkan kebaikan untuk pembesaran anak. Jawapan yang diberikan oleh anak kepada pihak hakim tentang kemahuan mereka untuk memilih sama ada untuk bersama-sama dengan pemohon atau responden, ternyata mereka lebih yakin dan berasa senang dengan kehidupan yang teratur di bawah pemeliharaan responden (Mimi Kamariah, 1998: 147).

Seperti yang dijelaskan sebelum ini, kekaburan yang berlaku terhadap pemahaman konsep hak perwalian dan hak hadanah anak menurut undangundang Islam di Malaysia sering kali berlaku terutamanya dalam kalangan masyarakat umum. Perkara yang sama juga berlaku dalam usaha memahami konsep hak penjagaan dan pemeliharaan anak kerana masih terdapat pihak yang sukar membezakan antara kedua-dua tanggungjawab tersebut dan menganggapnya sama. Kewujudan kecelaruan ini disokong oleh Normi (2011: 2244) yang menyatakan bahawa hubungan antara penjagaan dan pemeliharaan tidak dibezakan secara jelas dan tepat di bawah undangundang Malaysia. Persoalannya, adakah hak penjagaan anak sama seperti istilah legal custody, iaitu golongan yang diberikan secara undang-undang untuk memelihara anak? Bagaimanakah pula dengan tanggungjawab yang lain seperti mengasuh, mendidik dan membesarkan anak sekiranya anak yang masih kecil diberikan kepada penjaga mutlak terhadap anak yang sah daripadanya? Kesukaran untuk melihat perbezaan yang jelas antara hak dengan peranan bagi kedua-duanya dapat dilihat dalam kes Mohan Raj St Patmanathan v Prema Rani a/p Kandiah Ponnampalam \& Anor [2005] 4 MLJ 444 apabila pihak mahkamah memberikan hak pemeliharaan bersama kepada kedua-dua ibu bapa, dan juga hak jagaan dan pengawalan kepada pihak ibu.

Seperti hukum syarak, secara asalnya, hak penjagaan atau perwalian bermakna hak bapa terhadap diri anak untuk menentukan keputusan dalam hidup anak sehingga anak mencapai umur baligh atau dewasa. Malah bapa juga mempunyai hak untuk mengawal harta dan bertanggungjawab menanggung perbelanjaan kesihatan dan pendidikan bagi anak tersebut. Namun begitu, lama-kelamaan, pertelingkahan mula berlaku yang berpunca daripada perkembangan kesedaran pihak wanita terhadap hak wanita, yang mahu mendapatkan hak lawatan, hak pemeliharaan dan akhirnya memohon untuk mendapatkan hak penjagaan yang sama seperti seorang bapa. Akhirnya, timbul isu tentang siapakah yang paling berhak 
dan layak mendapatkan penjagaan anak dan membesarkannya serta menentukan masa hadapannya (Noor Aziah, 2007: 151). Di Malaysia, berdasarkan kepada seksyen 10 Akta Penjagaan Anak (Akta 351), mahkamah mempunyai hak untuk menentukan penjaga yang layak untuk menjaga anak dan menggantikannya sekiranya hilang kelayakan. Malah, mahkamah akan meneliti kebolehan dan kelayakan pihak yang memohon untuk memikul tanggungjawab sebagai seorang penjaga seperti yang diperuntukkan di bawah seksyen 3, iaitu:

\section{Duties of guardian of person}

3. The guardian of the person of an infant shall have the custody of the infant, and shall be responsible for his support, health and education.

Normi (2011: 2245) menegaskan lagi bahawa terdapat banyak ketidakpastian yang timbul berkaitan dengan peruntukan seksyen 3 dan seksyen 5 Akta 351, iaitu tentang tanggungjawab dan hak bagi ibu bapa dalam konteks hak penjagaan, sekiranya seorang yang diberikan hak pemeliharaan, yang secara langsung juga bertanggungjawab terhadap kesihatan, jagaan dan pendidikan anak. Selari dengan konsep kesamarataan antara hak ibu dengan hak bapa terhadap hak pemeliharaan anak, maka pihak ibu juga dilihat mempunyai hak yang sama dengan bapa dalam konteks penjagaan untuk menguruskan harta anak dan mengambil amanah serta kepercayaan bagi pihak anak. Permasalahan menjadi lebih rumit apabila berlaku perceraian antara ibu bapa yang menyebabkan mereka hidup secara berasingan. Maka timbul persoalan yang sukar untuk diberikan jawapan secara tepat menerusi peruntukan undang-undang kerana peruntukan dalam akta tidak menyebut secara jelas siapakah yang berhak sebagai penjaga hakiki atau mutlak kepada anak.

Persoalan lain yang juga akan timbul, adakah satu pihak yang mendapat hak pemeliharaan dan secara automatik dianggap sebagai penjaga, manakala yang tidak diberikan hak itu tidak dikira sebagai penjaga atau dipanggil dengan istilah yang lain secara undang-undang? Sekiranya hak jagaan diberikan kepada ibu berseorangan, adakah dia sendirinya yang akan bertanggungjawab untuk membesarkan anak? Konsep ini berbeza dengan peruntukan di bawah undang-undang Islam kerana sungguhpun 
hak hadanah anak boleh diberikan kepada golongan ibu atau bapa yang berkelayakan, namun hak perwalian dalam Islam (guardianship) tetap diberikan kepada bapa yang berhak untuk menentukan keputusan dalam kehidupan anak dan mengawal harta yang dimiliki oleh anak. Para wali juga bertanggungjawab untuk menentukan perkara penting yang melibatkan masa depan anak seperti agama, kepercayaan, perkahwinan dan pendidikan.

\section{KONFLIK HAK PEMELIHARAAN ANAK MUALAF SEBELUM PINDAAN AKTA MEMBAHARUI UNDANG-UNDANG (PERCERAIAN DAN PERKAHWINAN) 2017 (AKTA 164)}

Jika diteliti dalam kebanyakan konflik kes hak pemeliharaan anak bagi pasangan mualaf sebelum tahun 2017, isu perceraian merupakan antara penyumbang utama kepada pertikaian hak tersebut. Sebelum berlakunya pindaan, situasi yang sering kali terjadi ialah seseorang mualaf yang pernah berkahwin di bawah akta sivil ingin memohon perceraian, tetapi tidak mempunyai hak dari sudut perundangan. Apabila mereka gagal memohon perceraian di bawah mahkamah sivil, maka secara tidak langsung mereka juga tidak dapat meneruskan permohonan untuk mendapatkan hak pemeliharaan anak di bawah akta sivil. Sebelum ini Seksyen 51 Akta 164 hanya memperuntukkan bahawa:

Jika satu pihak kepada suatu perkahwinan telah masuk Islam, pihak yang satu lagi itu yang tidak masuk Islam boleh mempetisyen untuk perceraian;

Dengan syarat bahawa tiada sesuatu petisyen di bawah seksyen ini boleh diserahkan sebelum tamat tempoh tiga bulan dari tarikh masuk Islam itu.

Jelas sekali peruntukan di atas hanya membenarkan sebelah pihak sahaja, iaitu yang tidak memeluk Islam untuk memfailkan petisyen perceraian di bawah Akta 164. Selagi tindakan tersebut tidak dimulakan oleh mereka yang tidak memeluk Islam, maka perkahwinan tersebut akan dikira masih berlangsung dan pihak yang memeluk agama Islam masih terikat dengan tanggungjawab yang sah perkahwinan berdasarkan perkahwinan sivil yang telah didaftarkan. Masalah ketergantungan kes perceraian mualaf dapat dilihat dalam kes $\mathrm{Ng}$ Siew Pian lwn Abdul Wahid 
Abu Hassan dan Seorang lagi [1992] 2 MLJ 425, apabila salah seorang daripada pasangan bukan Islam memeluk Islam, tetapi pasangannya enggan memeluk Islam bersama-sama dengannya dan tidak pula memfailkan petisyen perceraian. Maka pembubaran perkahwinan telah cuba diisytiharkan oleh mahkamah syariah melalui permohonan pihak suami yang beragama Islam, tetapi ditolak oleh mahkamah tinggi sivil atas alasan mahkamah syariah tiada bidang kuasa untuk membatalkan perkahwinan yang melibatkan salah seorang pasangan bukan Islam. Bagi mahkamah sivil, perkahwinan tersebut telah didaftarkan di bawah Akta 164, maka segala hal ehwal perceraian dan tuntutan yang berkaitan dikawal oleh akta tersebut melalui Seksyen 51. Akan tetapi sebelum pindaan, pihak mualaf dilihat tidak mempunyai hak perundangan untuk memohon perceraian. Maka kebanyakan mualaf mengambil tindakan memohon perceraian dan hak pemeliharaan anak di bawah mahkamah syariah.

Dalam konteks pemakaian akta, tidak dinafikan bahawa seseorang yang beragama Islam tertakluk di bawah undang-undang syariah. Namun begitu, pembacaan penuh terhadap Seksyen 3(3) Akta Memperbaharui Undang-undang (Perkahwinan dan Perceraian) 1976 yang berkaitan dengan pemakaian akta perlulah dilakukan secara teliti. Pelaksanaan akta ini tidak hanya kepada yang beragama Islam dan berkahwin dengan kaedah Islam, tetapi juga bagi kes pihak yang pernah berkahwin dan telah mendaftarkan perkahwinannya di bawah Akta 164. Oleh itu, segala perkara berkaitan dengan perkahwinan tersebut di bawah bidang kuasa sivil dan dianggap masih wujud kecuali telah dibubarkan oleh mahkamah sivil. Antara objektif utama prinsip ini adalah untuk memastikan tiada pihak tertentu yang menggunakan pertukaran agama Islam sebagai kaedah untuk melepaskan diri daripada menunaikan tanggungjawab keluarga yang dipikul oleh mereka dalam perkahwinan terdahulu di bawah Akta 164. Perkara ini dapat dilihat melalui kes Kung Lim Siew lwn Chong Chee Kuan [2003] 6 MLJ 260, apabila perkahwinan yang dilalui oleh kedua-dua pasangan menghadapi beberapa masalah dan akhirnya membuat keputusan untuk tinggal secara berasingan. Namun begitu, apabila pihak isteri cuba mendapatkan hak yang sepatutnya mengikut kaedah undang-undang sivil, maka pihak suami cuba untuk menafikannya atas alasan telah memeluk agama Islam, maka mahkamah sivil tidak mempunyai bidang kuasa terhadap dirinya. Oleh yang demikian, mahkamah memutuskan bahawa sungguhpun akta tidak terpakai terhadap mereka yang beragama Islam, namun dalam kes tersebut defendan terhalang daripada menggunakan identiti Islam bagi tujuan mengelakkan dirinya daripada menyempurnakan 
tanggungjawab terhadap perkahwinan lama yang telah didaftarkan secara sah di bawah Akta 164. [2003] 6 MLJ (260: 266).

Antara konflik lain yang dibangkitkan sebelum pindaan 2017 adalah berkaitan dengan mahkamah kompeten yang mempunyai bidang kuasa penuh bagi membicarakan kes permohonan perceraian dan hak pemeliharaan anak kepada mualaf. Jika dirujuk huraian Y.A. Hakim Mahkamah Agung, Mohamed Dzaiddin dalam kes Tan Sung Mooi lwn Too Miew Kim [1994] 3 MLJ 117, mahkamah yang paling layak bagi membicarakan kes sebegitu ialah mahkamah sivil kerana bidang kuasa mahkamah untuk tetap mempunyai kuasa untuk mendengar, mengeluarkan perintah berkaitan dengan perceraian dan tuntutan sampingan lain seperti nafkah sara hidup dan hak pemeliharaan anak. Alasan yang diberikan oleh mahkamah ialah petisyen pembubaran perkahwinan tersebut didaftarkan di bawah seksyen 76 \& 77 Akta Memperbaharui Undang-undang (Perkahwinan dan Perceraian) 1976 yang melibatkan pihak perceraian bukan Islam. Sungguhpun ketika itu salah satu pihak telah bertukar agama kepada agama Islam, namun kedua-dua pemohon dan responden dalam kes tersebut bukan beragama Islam semasa mendaftarkan perkahwinan mereka dan telah melangsungkan perkahwinan mengikut tatacara keagamaan bukan Islam. Oleh yang demikian, pastinya mahkamah sivil yang merupakan mahkamah yang kompeten untuk membicarakan kes tersebut. Selain itu, mahkamah agung juga memutuskan bahawa sungguhpun Perkara 121(1A) Perlembagaan Persekutuan mengeluarkan bidang kuasa mahkamah tinggi sivil daripada mendengar perkara yang termasuk dalam bidang kuasa mahkamah syariah, tetapi pada masa yang sama juga harus difahami bahawa mahkamah syariah juga tidak mempunyai bidang kuasa terhadap perbicaraan yang melibatkan pihak bukan Islam. Oleh itu, Perkara 121(1A) tidak memberikan kesan terhadap bidang kuasa mahkamah tinggi untuk mendengar sebarang bentuk permohonan di bawah seksyen 76 dan seksyen 77 Akta Memperbaharui Undang-undang (Perkahwinan dan Perceraian) 1976 kerana melibatkan dua pihak yang pernah berdaftar di bawah akta perkahwinan sivil (Noor Aziah, 2005).

Dalam kes Viran a/l Nagupan lwn Deepa a/p Subramaniam [2015] 3 MLJ 209, pertindihan tuntutan terhadap hak pemeliharaan anak berlaku apabila pihak isteri menggunakan mahkamah sivil sebagai platform untuk menuntut haknya. Suami yang telah memeluk Islam pula mengambil langkah untuk memfailkan tuntutan hadanah di bawah mahkamah syariah atas faktor keterikatan beliau kepada undang-undang syariah setelah bergelar Muslim. Namun begitu, akhirnya mahkamah persekutuan 
memutuskan bahawa tuntutan berkaitan dengan individu yang pernah berkahwin mengikut tatacara undang-undang sivil, iaitu di bawah Akta 164, maka mahkamah sivil menjadi platform terbaik untuk mendengar kes tersebut. Yang menariknya, dalam penilaian terhadap prinsip mengutamakan kepentingan anak dapat dilihat dengan jelas apabila pandangan anak tersebut diambil dan diraikan oleh pihak mahkamah yang mengadilinya. Hal ini penting bagi mengelakkan tekanan perasaan dan gangguan emosi anak jika diletakkan secara paksa untuk memilih sama ada hidup bersama-sama dengan ibu atau bapa yang tidak mampu memberikan kebaikan dan kebajikan untuk diri anak.

Sebelum berlakunya pindaan 2017, mahkamah syariah pernah bertindak menerima permohonan perceraian daripada mualaf dan meneruskan prosiding perceraian atas sebab pemohon memeluk Islam. Jika dirujuk pada kes Permohonan Perisytiharan pembubaran perkahwinan Di Sebabkan Pertukaran Agama oleh Siti Aisyah_Janthip Aisam JH xxi/ II (2006) 262 yang diputuskan oleh pihak Mahkamah Tinggi Syariah Kuala Terengganu, pada awalnya pihak mahkamah telah melakukan beberapa prosedur undang-undang sebelum menerima permohonan untuk membubarkan perkahwinan tersebut atas sebab plaintif memeluk agama Islam. Antaranya termasuklah memanggil pihak suami untuk memberikan keterangan berkaitan dengan perkahwinan dan menjelaskan tentang implikasi pembubaran terhadap perkahwinan tersebut sekiranya masih enggan memeluk agama Islam. Maka perkahwinan tersebut diisytiharkan terbubar atas sebab pertukaran agama oleh isteri yang memeluk Islam. Jika dilihat, fakta yang sama juga berlaku dalam kes Permohonan Perisytiharan Pembubaran Perkahwinan kerana Pemelukan Islam Nur Adryana Qestina bt Abdullah JH (2008) 25/1,157 yang diputuskan oleh Mahkamah Tinggi Syariah Seremban. Pihak mahkamah telah membubarkan perkahwinan plaintif dan suaminya yang bukan beragama Islam, iaitu Gopal a/l Subramaniam. Akhirnya pihak mahkamah telah mengesahkan pembubaran perkahwinan tersebut berpandukan bidang kuasa yang diperuntukkan kepadanya seperti yang terkandung dalam Seksyen 46(2) Enakmen Undang-undang Keluarga Islam (Negeri Sembilan) 2003 atas faktor memeluk agama Islam oleh salah seorang daripada pasangan yang telah berkahwin. Dalam kedua-dua kes tersebut, usaha memujuk pihak suami agar turut memeluk agama Islam telah dilakukan namun tidak memberikan sebarang kesan, walaupun telah difahami tentang kesan pembubaran yang bakal dihadapinya. Oleh yang demikian, tindakan pihak mahkamah dilihat selari dengan kaedah hukum syarak yang memberikan 
ruang pengadilan yang sempurna kepada kedua-dua pihak tanpa sebarang paksaan. Perkahwinan lama bagi pasangan bukan Islam tidak boleh diteruskan dan dianggap terbatal oleh hukum syarak. Namun begitu, pihak mualaf masih perlu menunaikan tanggungjawab terhadap perkahwinan lama seperti pemberian nafkah kepada anak di bawah umur.

Di samping itu, konflik berkaitan dengan bidang kuasa antara syariah dengan sivil juga dapat dilihat dalam kes Shamala a/p Sathiyaseelan lwn Dr. Jeyaganesh a/l C Mogarajah [2004] 2 MLJ 241. Terdapat pandangan pakar undang-undang yang menyatakan bahawa mahkamah syariah dilihat telah mendengar perbicaraan kes yang berada di luar peruntukan bidang kuasa kerana melibatkan pertikaian seorang Islam dan bukan Islam. Adalah lebih baik sekiranya berlaku permohonan perceraian, hak pemeliharaan anak dan nafkah atau apa-apa tuntutan berkaitan dengan mualaf, maka diketepikan dahulu oleh mahkamah syariah pada peringkat awal dan menasihati agar diselesaikan dahulu keterikatan mualaf dengan perkahwinan terdahulu yang berada di bawah akta sivil (Noor Aziah, 2004: 6). Pendekatan yang akhirnya digunakan oleh mahkamah sivil bagi menyelesaikan kes tersebut ialah konsep hak pemeliharaan dan penjagaan anak secara bersama antara ibu bapa yang Islam dengan bukan Islam. Hakim mahkamah tinggi sivil telah menyerahkan hak memelihara dan mengawal anak-anaknya yang meliputi penjagaan seharian kepada emaknya. Hakim Dato' Faiza juga menyatakan bahawa hak penjagaan anak-anak itu diberikan kepada kedua ibu bapa agar mereka bersetuju terhadap isu-isu berkaitan dengan anak-anak seperti pendidikan, dan pilihan terhadap agama dan harta. Penghakiman tersebut mengambil kira inti pati peruntukan seksyen 5 Akta Penjagaan Anak 1961 yang menyebut tentang hak kesamarataan kepada ibu bapa dalam konteks menjaga kebajikan anak. Namun demikian, tidak dinafikan bahawa kemelut undang-undang masih berpotensi untuk berlaku meskipun perintah kaveat telah diberikan, iaitu pihak ibu harus memahami status anak sebagai mualaf yang sah dan tidak boleh mempengaruhinya dengan ajaran selain Islam dan dilarang memberikan makanan yang tidak halal. Hal ini disebabkan pihak mahkamah tidak memberikan kaedah yang jelas atau mengesyorkan garis panduan yang tepat bagi memastikan emak yang bukan Muslim mematuhi larangan yang diperintahkan oleh mahkamah. Selain itu, perintah kaveat yang dikeluarkan juga boleh dipertikaikan kerana mempunyai unsur percanggahan dengan konsep pemberian hak pemeliharaan bersama kepada ibu dan bapa yang bermaksud kedua-dua pihak hendaklah bersetuju untuk memelihara kebajikan anak (Mohamed Azam, 2014: 11). 


\section{IMPLIKASI PINDAAN AKTA 164 (2017) TERHADAP HAK PEMELIHARAAN ANAK BAGI PASANGAN MUALAF}

Pelbagai pihak dalam kalangan pengamal dan pakar undang-undang telah menyimpulkan bahawa pindaan terhadap beberapa seksyen utama dalam Akta 164 perlu dilakukan bagi menyelesaikan konflik hak pemeliharaan anak bagi mualaf. Prinsip pokok yang perlu diutamakan terhadap pindaan tersebut ialah memberikan remedi kepada mualaf yang selama ini terabai dan juga mahu meletakkan autoriti kepada mahkamah sivil yang dirasakan lebih sesuai dan kompeten untuk menentukan pihak yang paling layak untuk memelihara kebajikan dan memberikan kebaikan kepada anak hasil daripada perkahwinan sebelum ini. Kebanyakan sarjana menyebut bahawa punca pertikaian ialah seksyen 51 Akta Memperbaharui Undang-undang (Perkahwinan dan Perceraian) 1976, memandangkan sejak bermulanya pelaksanaannya, kaedah penyelesaian agak kabur dan berat sebelah kerana pihak yang memeluk Islam tidak mendapat keadilan sepenuh untuk membubarkan perkahwinan, sekali gus menyebabkan ramai pihak mencadangkan supaya seksyen tersebut dilakukan pindaan (Ahmad, 1997, Noor Aziah, 1999: 127). Malah Mohamed Azam dan Rafeah (2016: 70) juga menyarankan supaya peruntukan di bawah Akta 164 yang berkaitan dengan konflik hak pemeliharaan anak bagi pasangan yang memeluk Islam perlu dipinda sebaik-baiknya bagi memastikan kebajikan anak terpelihara dan tidak menjadi mangsa dalam kes perceraian mualaf.

Begitu juga dengan Zuliza dan Nurhidayah (2016: 38) yang menjelaskan motif cadangan pindaan Seksyen 51 Akta Memperbaharui Undang-undang (Perkahwinan dan Perceraian) 1976 adalah untuk memberikan hak yang sama rata kepada semua, sama ada pihak suami atau isteri, untuk memfailkan perceraian setelah memeluk Islam dan seterusnya berhak mendapatkan pengadilan dari sudut undang-undang bagi tuntutan sampingan yang lain. Malah pindaan yang dibuat pada Seksyen 3 Akta 164 (Pindaan 2017) berjaya menetapkan kuasa mahkamah sivil secara eksklusif untuk mendengar permohonan perceraian yang melibatkan pertukaran agama kepada Islam bagi golongan mualaf dengan merujuk Seksyen 51 atau mana-mana seksyen lain yang bertujuan untuk membubarkan perkahwinan melalui persetujuan bersama atau pecah-belah perkahwinan masing-masing di bawah seksyen 52 dan juga seksyen 53 . Maka tidak timbul lagi soal pemakaian Akta 164 kepada mualaf walaupun setelah beragama Islam. Seterusnya, melalui pindaan ini juga mahkamah sivil diberikan kuasa secara langsung untuk menyelesaikan tuntutan lain 
yang berkaitan setelah berlaku perceraian seperti harta sepencarian dan juga hak jagaan anak (Mohamed Azam, 2017: 3). Terkini, berkuat kuasa pada tahun 2017, seksyen 3 dan seksyen 51 Akta Memperbaharui Undangundang (Perkahwinan dan Perceraian) 1976 telah dipinda seperti di bawah:

\section{Seksyen 3:}

Subseksyen 3(3)-

(a) Akta ini tidak terpakai bagi seseorang Islam atau bagi mana-mana orang yang berkahwin di bawah undang-undang Islam dan tiada perkahwinan boleh diupacarakan atau didaftarkan di bawah Akta ini jika salah satu daripada pihak-pihak kepada perkahwinan itu menganut agama Islam; tetapi tiada apa-apa jua dalam seksyen ini boleh diertikan sebagai menghalang suatu mahkamah daripada mempunyai bidang kuasa eksklusif atas pembubaran sesuatu perkahwinan dan semua perkara yang berbangkit daripada itu termasuklah memberi dekri perceraian atau perintah lain di bawah Bahagian VII dan Bahagian VIII bagi:

(a) suatu petisyen perceraian di bawah seksyen 53 yang satu pihak masuk Islam selepas petisyen difailkan atau selepas dekri diisytiharkan; atau

(b) suatu petisyen perceraian di bawah seksyen 51, 52 atau 53 bagi petisyen oleh salah satu pihak atau kedua-dua pihak kepada suatu perkahwinan yang satu pihak telah masuk Islam;", dan dekri itu dan perintah yang dibuat adalah, walau apa pun undang-undang bertulis lain yang berlawanan, sah terhadap pihak kepada perkahwinan itu yang telah masuk Islam sedemikian itu.

Seksyen 51:

(1) Jika satu pihak kepada sesuatu perkahwinan telah masuk Islam-

(a) salah satu pihak boleh mempetisyen untuk perceraian di bawah seksyen ini atau seksyen 53; atau

(b) kedua-dua pihak boleh mempetisyen untuk perceraian di bawah seksyen 52 .

(2) Mahkamah boleh, apabila membubarkan perkahwinan itu atau pada bila-bila masa, membuat peruntukan untuk isteri atau suami, dan 
untuk nafkah, pemeliharaan dan penjagaan anak daripada perkahwinan itu, jika ada di bawah Bahagian VII dan Bahagian VIII, dan boleh mengenakan apa-apa syarat ke atas dekri pembubaran itu sebagaimana yang difikirkannya patut.

(3) Seksyen 50 tidak terpakai bagi apa-apa petisyen untuk perceraian jika satu pihak telah masuk Islam.

\section{Seksyen 52:}

Jika suami dan isteri bersetuju secara bersama bahawa perkahwinan mereka hendaklah dibubarkan mereka boleh, selepas tamat dua tahun dari tarikh perkahwinan mereka, mengemukakan suatu petisyen bersama dengan sewajarnya dan mahkamah boleh, jika ia fikirkan patut, membuat suatu dekri perceraian apabila berpuas hati bahawa kedua-dua pihak itu bersetuju secara bebas dan bahawa peruntukan yang sepatutnya dibuat bagi isteri itu dan bagi nafkah, pemeliharaan dan penjagaan anak, jika ada, daripada perkahwinan itu, dan boleh mengenakan apa-apa syarat ke atas dekri perceraian itu sebagaimana yang difikirkannya patut.

Secara ringkasnya, implikasi pindaan di atas terhadap proses permohonan hak pemeliharaan anak bagi mualaf dapatlah dirumuskan seperti di bawah:

(1) Pertama, seksyen 3 Akta Memperbaharui Undang-undang (Perkahwinan dan Perceraian) 1976 (Pindaan 2017) yang memberikan bidang kuasa eksklusif kepada mahkamah sivil untuk membicarakan dan memutuskan kes tentang pembubaran perkahwinan dan segala perkara yang berbangkit bersamanya termasuklah apabila salah seorang pasangan yang berkahwin di bawah Akta 164 tersebut telah memeluk agama Islam. Pindaan tersebut adalah untuk menyelesaikan permasalahan berkaitan dengan status perkahwinan mualaf yang terdahulu seperti dalam kes Letchumy lwn Ramadason [1984] 1 MLJ 143 apabila pihak isteri mahu menuntut perceraian dengan merujuk seksyen 54(c) Akta 164 atas alasan suaminya meninggalkannya dalam suatu tempoh yang berterusan. Malangnya permohonannya ditolak oleh pihak mahkamah kerana pihak suami berhujah bahawa peruntukan di bawah Akta 164 tidak lagi terpakai terhadapnya memandangkan beliau telah memeluk agama Islam. Keputusan tersebut mencetuskan pelbagai kekeliruan sehingga ada pihak yang mempersoalkan sama ada pemelukan Islam boleh dijadikan sebagai jalan keluar untuk 
melepaskan diri daripada tanggungjawab yang perlu dilaksanakan sebelum memeluk Islam (Najibah, 2018: 398). Oleh yang demikian, pindaan yang dilakukan telah meletakkan mahkamah sivil secara sah mempunyai bidang kuasa terhadap segala kes berkaitan dengan mualaf yang memeluk agama Islam dengan syarat perkahwinannya sebelum pengislaman mestilah berdaftar di bawah undang-undang sivil. Sekiranya perkahwinan tersebut sekadar dilakukan mengikut upacara agama atau adat semata-mata tetapi tidak atau belum didaftarkan, maka pihak mahkamah sivil tetap tidak mempunyai sebarang kuasa atas pembubaran terhadap ikatan perkahwinan tersebut.

(2) Kedua, Seksyen 51 Akta Memperbaharui Undang-undang (Perkahwinan dan Perceraian) 1976 (Pindaan 2017) yang akhirnya membolehkan kedua-dua pihak suami isteri yang memeluk Islam atau tidak beragama Islam untuk mengemukakan petisyen perceraian atas alasan pengislaman pasangannya selepas tempoh tiga bulan bermula waktu pemelukan Islam. Implikasi positif hasil daripada pindaan ini ialah pelaksanaannya mampu memberikan remedi tepat kepada mana-mana mualaf yang terlibat dengan perceraian atas sebab pemelukan Islam di bawah seksyen 51 Akta 164. Seperti yang diketahui keadaan sebelum ini memperlihatkan bahawa tindakan seorang mualaf untuk memeluk Islam seolah-olah menjadi suatu kesalahan matrimony yang membawa kesan penafian terhadap hak dirinya untuk memohon pembubaran di bawah akta sivil (Zuliza et al., 2017: 19). Malah Seksyen 51 Akta 164 juga meletakkan mualaf yang telah berkahwin dalam keadaan kekeliruan dan terpaksa menghadapi masalah birokrasi perundangan untuk menuntut haknya. Pindaan tersebut dapat memberikan mualaf suatu lokus standi atau hak dari sudut undang-undang untuk mendapatkan tindakan mahkamah bagi memfailkan petisyen pembubaran perkahwinan terdahulu, yang selama ini hak tersebut hanya diberikan kepada pasangannya yang tidak memeluk Islam. Maka ketidakadilan terhadap hak mualaf seperti dalam kes Eswari Visuvalingam lwn Kerajaan Malaysia [1990] 1 MLJ 86, apabila pihak pasangan bukan Islam sengaja tidak mahu atau enggan memfailkan petisyen perceraian, maka pihak mualaf bolehlah memohon perceraian berpandukan tempoh waktu yang ditetapkan oleh undang-undang. 
(3) Akhirnya, kelancaran proses perceraian melalui pindaan tersebut secara langsung memudahkan proses tuntutan relief sampingan, iaitu dalam bab hak pemeliharaan anak oleh pihak mualaf dan juga pasangan yang bukan Islam. Malah proses perbicaraan permohonan hak pemeliharaan akan lebih mudah dan teratur kerana dibicarakan di bawah satu mahkamah yang sama dan merujuk akta undangundang sivil. Tidak berlaku lagi pertikaian bidang kuasa mahkamah dan pertindahan perintah mahkamah antara sivil dengan syariah kerana semua proses dapat dilaksanakan secara harmoni. Di samping itu, melalui Akta Memperbaharui Undang-undang (Perkahwinan dan Perceraian) 1976 (Pindaan 2017) dapat memahamkan golongan mualaf bahawa mereka tetap tertakluk pada akta perkahwinan dan perceraian sivil untuk membubarkan perkahwinan terdahulu. Tidak seharusnya dibangkitkan ketidaksahan pemakaian akta sivil terhadap mereka atas alasan telah memeluk agama Islam kerana terdapat perkara penting yang terbit hasil daripada perkahwinan terdahulu, iaitu permohonan hak pemeliharaan anak yang perlu mengikut kaedah undang-undang sivil. Secara prinsipnya, setiap sesuatu itu hendaklah diselesaikan berdasarkan sesuatu itu bermula. Maka dalam kes perceraian dan hak pemeliharaan anak yang bermula dengan ikatan perkahwinan dan penghasilan anak adalah di bawah undang-undang sivil, maka sewajarnyalah diselesaikan dengan peruntukan akta yang sama supaya tidak menimbulkan konflik yang lebih besar.

\section{CADANGAN PENAMBAHBAIKAN}

Permasalahan dalam penetapan hak pemeliharaan anak bagi pasangan beragama Islam dan bukan Islam masih berpotensi untuk berlaku berpunca daripada interpretasi undang-undang sivil dan penghakiman mahkamah terhadap keutamaan kebajikan anak berpandukan kepada seksyen 88 Akta 164 dan juga seksyen 11 Akta 351. Kebajikan anak dalam enakmen tersebut tidak disenaraikan secara tepat dan jelas menyebabkan berlaku kekaburan terhadap elemen yang perlu diutamakan mengikut hierarki yang sepatutnya. Cadangan yang boleh dilaksanakan ialah penyediaan garis panduan yang jelas untuk dirujuk oleh pihak mahkamah tinggi sivil supaya kebajikan anak dapat diletakkan tepat pada tempatnya. Pendapat hukum syarak dan peruntukan undang-undang Islam tentang kebajikan anak juga boleh diambil kira oleh pihak mahkamah sekiranya mampu 
menyumbang kepada penyelesaian yang lebih holistik terhadap konflik hak pemeliharaan anak bagi perkahwinan mualaf. Tidak wujud sebarang percanggahan yang nyata tentang kebajikan anak menurut perspektif undang-undang Islam mahupun sivil kerana peruntukan hukum syarak sentiasa mementingkan fleksibiliti dalam pengamalan kehidupan seharian terutamanya yang melibatkan hubungan Islam dengan agama-agama lain.

\section{KESIMPULAN}

Secara kesimpulannya, dapatlah dilihat bahawa perceraian atas faktor pemelukan agama Islam oleh mualaf sering kali mengundang pertikaian hak pemeliharaan anak atas faktor konflik bidang kuasa antara mahkamah sivil dan syariah serta rujukan undang-undang bagi kedua-duanya, terutamanya sebelum berlakunya pindaan pada Akta Memperbaharui Undang-undang (Perkahwinan dan Perceraian) 1976 (Pindaan 2017). Akan tetapi selepas beberapa seksyen utama yang berkaitan dengan pertikaian tersebut seperti seksyen 3 dan seksyen 51 Akta Memperbaharui Undangundang (Perkahwinan dan Perceraian) 1976 telah dipinda, maka punca utama pertikaian telah dapat diselesaikan secara adil. Ternyata pindaan yang dibuat terhadap peruntukan undang-undang tersebut menghasilkan keadilan yang holistik kerana membolehkan kedua-dua belah pihak, sama ada Islam atau bukan Islam, untuk memfailkan petisyen perceraian. Pindaan ini memudahkan urusan mereka untuk menuntut hak pemeliharaan anak di bawah mahkamah yang mempunyai bidang kuasa.

Begitu juga dengan pindaan peruntukan undang-undang yang memberikan kuasa eksklusif kepada pihak mahkamah tinggi sivil untuk menguruskan kes perceraian bagi salah seorang pasangan yang telah memeluk Islam. Hal ini bukanlah suatu isu yang perlu diperbesar atas alasan perbicaraan kes melibatkan orang Islam kerana secara prinsipnya sebarang bentuk perkahwinan yang pernah diupacara atau didaftarkan di bawah mana-mana akta sivil atau enakmen syariah, maka perkahwinan tersebut perlu dibubarkan dan sebarang tuntutan relief sampingan haruslah dibuat di bawah akta sivil atau enakmen syariah tersebut bagi mewujudkan keadilan kepada kedua-dua belah pihak. Tambahan pula, perbuatan mengislamkan diri oleh golongan mualaf tidak boleh dijadikan alasan serta merta untuk melepaskan diri daripada keterikatan dengan komitmen perkahwinan yang lalu di bawah mahkamah sivil. Pindaan kuasa perbicaraan juga dilihat bersesuaian dengan amalan prinsip penyelesaian di bawah satu mahkamah seperti yang sering diamalkan di negara ini. 
Pelaksanaannya penting kerana mampu mewujudkan keharmonian dan kesejahteraan dalam kalangan masyarakat Malaysia yang terdiri daripada pelbagai kaum dan agama.

\section{RUJUKAN}

Abu Dawud. (1984). Sunan Abu Dawud (Jil. 2). Terjemahan Inggeris oleh Prof. Ahmad Hassan, Lahore: Sh. Muhammad Ashraf Publishers \& Booksellers Akta Perkahwinan dan Perceraian (Akta 164)

Andrew I.Scepard. (2004). Children, courts, and custody: interdisciplinary models for divorcing families. United Kingdom: Cambridge University Press Ahmad Ibrahim. (1997). Family law in Malaysia. Selangor: Malayan Law Journal. al-Jaziri, Abd al-Rahman. (1969). Al-Fiqh 'ala al-Madhahib al-Arba'ah (Jil. 4). Kaherah: Maktabah al-Tijariyyah al-Kubra.

al-Sharbini, Muhammad al-Khatib. (1978). Mughni al-Muhtaj 'ila Ma'ani alfaz al-Minhaj (Jil 3). Beirut: Dar al-Fikr.

al-Zuhaily Wahbah. (1997). Al-fiqh al-Islami wa adillatuhu (Jil. 7). Dimashq: Dar al-Fikr.

Dina Imam Supaat. (2012). The principle of best interests of the child as the basis of state obligation to protect refugee children in Malaysia. South East Asian Journal of Contemporary Business Economic and Law.

Ibn Qudamah al-Maqdisi. (t.t.). Al-Mughni (Jil. 7). Beirut: Dar al-Fikr.

Khadijah Mohd Khambali @ Hanbali. (1994). Perkahwinan ahl al-kitab: Suatu kajian hukum. Jurnal Syariah, 2(2). Universiti Malaya: Fakulti Syariah.

Mehrun Siraj. (2012). Resolving child custody disputes: The law \& practice in Malaysia, Selangor: LexisNexis Sdn Bhd.

Mohamad Azam Mohamed Adil. (2006). Perundangan dan kenegaraan Islam. Selangor: iBook Publication Sdn Bhd.

Mohamed Azam Mohamed Adil \& Rafeah Saidon (2017). Religion as a determinant of child welfare in custody cases in Malaysia and classical Islamic law: A comparative overview. Islam and Civilisational Renewal, ICR 8.1 Produced and distributed by IAIS Malaysia.

Mohamed Azam bin Mohamed Adil. (2014). Penentuan agama dan hakpenjagaan anak-anak dalam undang-undang Islam. Putrajaya: Jabatan Kebajikan Islam Malaysia.

Mohamed Azam bin Mohamed Adil \& Rafeah Saidon. (2016). Religion as a determinant of child welfare in custody cases. Proceedings oF ICWC 2016. Subang Jaya, Malaysia.

Mohamed Azam bin Mohamed Adil \& Rafeah Saidon. (2017). Diakses daripada http://www.iais.org.my/e/attach/2017/29AUG2017/DrMohamedAzam.pdf 
Mimi Kamariah Majid. (1998). Undang-undang Keluarga di Malayia, Kuala Lumpur, Butterworths Asia.

Najibah Mohd. Zin. (2018). Akta membaharui (perkahwinan dan perceraian) (Pindaan) Akta 1976. Kanun: Jurnal Undang-undang Malaysia, 30(1).

Narizan Abdul Rahman. (2007) Hak Kekeluargaan Pasangan Berlainan Agama, Dlm. Ahmad Hidayat Buang (Ed.), Undang-undang Islam di Malaysia: Prinsip dan amalan. Kuala Lumpur: Penerbit Universiti Malaya.

Noor Aziah Mohd Awal. (2005). Child's right to religion in Malaysia: An overview. IKIM Law Journal, Special Edition in Memory of Ahmad Ibrahim, $9(1), 311$.

Noor Aziah Mohd Awal. (1999). Section 51 of Law Reform (Marriage \& Divorce) Act 1976: An overview. [1999] IKIM Law Journal, Vol 3 No2, Kuala Lumpur: Insititut Kefahaman Islam Malaysia.

Noor Aziah Mohd Awal. (2004). Pertukaran agama: Hak penjagaan anak-isu dan masalah religious conversion [2004] MLJ xxxiv.

Noor Aziah Mohd Awal. (2007). Penjagaan dan pemeliharaan anak. Dlm. Shamsuddin Sohor \& Noor Aziah (Eds.), Undang-undang Keluarga (Sivil). Kuala Lumpur: Dewan Bahasa dan Pustaka.

Normi Abdul Malek. (2007). Hadanah. Dlm. Najibah Mohd Zin (Ed.), Undangundang Keluarga (Islam). Kuala Lumpur: Dewan Bahasa dan Pustaka.

Normi Abdul Malek. (2004). Hadanah menurut undang-undang Islam dan pelaksanaannya di Malaysia. Jurnal Undang-undang IKIM Law Journal. Kuala Lumpur: Insititut Kefahaman Islam Malaysia

Normi, 2011. Unresolved issues in custody matters: The position in Malaysia, Journal of Applied Sciences Research, 7(13), 2240-2248.

Norliah Ibrahim, Najibah Mohd Zin, Nora Abdul Hak, Roslina Che Soh, Noraini Md. Hashim, Normi Abdul Malek, Azizah Mohd \& Mohd Hisham Mohd Kamal. (2011). Family law (non-muslim) in Malaysia. Selangor: IIUM Press. Raihanah Abdullah. (2007). Hak nafkah dan hadanah. Dlm. Ahmad Hidayat Buang (Ed.),Undang-undang Islam di Malaysia: Prinsip dan amalan. Kuala Lumpur: Penerbit Universiti Malaya.

Ramizah Wan Muhamad. (2009). Administration of Islamic judicial system in ASEAN countries with particular reference to Malaysia. Saarbruken: LAP Lambert Academic Publishing AG \& Co KG.

Shamsuddin Suhor. (2011). Panduan Akta Membaharui Undang-Undang Perkahwinan dan Perceraian 1976 (Akta 164). Kuala Lumpur: Dewan Bahasa dan Pustaka

Uqlah, Muhammad. (1984). Nidzam al-usrah fi al-Islam. Amman: Maktabah alRisalah al-Hadithah.

Zuliza Mohd Kusrin, Mohd Zamro Muda, Md Yazid Ahmad \& Mohd Al-Adib Samuri. (2017). Perkembangan penghakiman kes-kes pemelukan Islam dan 
implikasi perundangan terhadap pindaan rang undang-undang seksyen 51A dan 88A Akta 164. Isu Syariah dan Undang-Undang Siri 23.

Zuliza Mohd Kusrin \& Nurhidayah Muhammad Hashim (2016). Pemelukan Islam pasangan perkahwinan sivil: Isu berbangkit dan cadangan penambahbaikan menurut undang-undang Malaysia. Kanun: Jurnal Undang-undang Malaysia, 28(1).

Diperoleh (received): 07 Disember 2020

Diterima (accepted): 21 Disember 2020 